\title{
An Alternative to Learning Basketball Game Using TGFU (Teaching Games For Understanding)
}

\author{
By \\ Yudha Febrianta, M.Or \\ Universitas Muhammadiyah Purwokerto \\ Indonesia \\ yudha.febrianta@yahoo.co.id
}

\begin{abstract}
Teaching sport practice in schools still used drilling method with less cardiorespiratory development dimension which affects the students' intensity in less and minimal move. cardiorespiratory development is to improve fitness, one of them is by basketball game. The learning method should make students active. The method used is a TGfU model (Teaching Games for Understanding). Basketball learning using TGfU basketball has several indicators, namely indicators of skill execution, decision making, support, and defending.

The indicatorof skill execution includes: reaching the target at the time of passing by using three types of passing. Decision making includes: the decision to pass to teammates and to choose any shooting appropriately. Support includes: a willingness to move to obtain the right position. Defending includes: blocking the ball and the opponent. Scoring includes creating a score to win. Game Appreciation is the application of the values in the game.
\end{abstract}

Keyword: basketball games, TGfU Teaching Games for Understanding

\section{Introduction}

Education is not optimal tobuild the quality of the human resources. In fact, education has a very important role in ensuring the survival of the state, because education is a means to improve and develop the quality of human resources. Physical educationis a part of the education that cannot be separated in the formation of human resources quality, since the the instilled characteristics referring to the national educationis to develop the Indonesian human resources in a whole.

Physical Sport and Health Education is an integral part of the overall education, aiming to develop aspects of physical fitness, motor skills, critical thinking skills, social skills, reasoning, emotional stability, moral action, healthy lifestyles and the introduction of clean environment through physical activity, sport and health which are systematically planned in order to achieve national education goals (BSNP, 2006: 197). During the study, students play the role of both associated with physical and mental physical spiritual. Learning environment is carefully arranged to promote growth and development across thestudents' physical, psychomotor, cognitive, and affective domains of each student. As a process of education, physical education in the learning process involves various elements. These elements are teachers, pupils, the subject matter, media or infrastructure, methods, and goals. Realizing that education has a superior quality in all areas then it must be supported with good cardiorespiratory fitness.
Therefore, it can provide basic capital needs of cardiorespiratory fitness through physical and sports education subject held at the school.

Schools have not been successful / optimal in developing cardiorespiratory fitness in the learning process of physical education. Cardiorespiratory fitness is defined as the quality of human resources, because human with healthy heart and lungs will not have problems in their function so that people can do a good job. But all have not been optimal, this happens because the material being taught by the schools tend to be more theoretical than practical. In addition, physical education policy has not yet focused on the importance to support the development of Cardiorespiratory fitness, as stated in the Law of the Republic of Indonesia No. 20 of 2003 on National Education System Article 42 especially the curriculum contents of primary and secondary education that establishes teaching physical education as a subject must be given at the school from primary level to upper secondary education. (Ayi Suherman (2009: 2) As the illustration, physical education in junior high school teaches a wide range of basic motion in sports. The basic motion taught aims to make students able to do sports activities as well as to improve the physical fitness of students. The materials taught is football, volleyball, basketball, badminton, softball, table tennis, track and 50 meters' field sprint, athletic running with middle distance, athletics (high jump), martial, development activities, gymnastics, rhythmic gymnastics, and swimming. One of 
the teaching materials that will be discussed is basketball. Basketball game has grown in popularity in recent years. Many of the basketball clubs appear to participate in the competition. Some marginal schools have built a basketball field for learning physical education. Basketball Gamesfeaturebasic motion, passing, dribbling, and shootingskills.Each player displayshis highly skilled motion and is agile in doing the game, therefore it seems so beautiful to see in a basketball game. Learning basketball in junior high school is a different and new thing for junior high school students because there is not necessarily a basketball court in Primary School. Playing skills is taught to students as their assetto do basketball game. Learning basic motion taught by aPhysical educationteacher in junior high is carried out in accordance with the standards of competence and basic competences of an instructional material and began to be taught to students of grade VII.

The development of cardiorespiratory is done by exercising properly and in accordance with the needs of students in the school. However, teaching sport practice in schools still used drilling method, cardiorespiratory development dimension is less developedbecause drilling method makes students wait or queue for long time, the intensity of the students in a move is not long or maximum. At school, a lot of games can be done to improve cardiorespiratory fitness, one of them is basketball game.

Teaching basketball games can be done through a variety of learning methods. However, during physical education teachers in schools teach using drilling method. Students are required to perform the same movements with the tempo and intensity according to the instructions of the teacher. Students sometimes feel bored because the activities are just repeating the movement. There is a basketball instructional approach to deliver learning approach, one of them is a tactic approach or TGfU (Teaching Games for Understanding).

In line with Metzler (2000: 12), he states that the model is designed to be used in the overall learning unit including all the functions of planning, design, implementation, and assessment of the unit. More than one type of learning methods, teaching styles, as well as learning strategies can be used in onelearning model. As stated by Griffin (2005: 1), Teaching Games for Understanding (TGfU) learning modelis a game and students centered learning to learn the game related to sports by using a constructive approach.

In teaching the basic motion of basketball, the teachers of physical health and sportseducationhave already used the handbook of physical health and sports education. The books used by teachers include all sports that are taught, but drilling and instruction methods are still applied so that the students must wait and queue to do activities, while the TGfU (Teaching Games for Understanding) approach will make learning more active.

Students learn the basic motions in accordance with the instructions of a physical and and sports health education teacher Activities undertaken by students are lined up by teachers to organize students for being in order by instructions and drilling.But when using TGFU, students will engage all the small game so that no student is waiting to do the passing, dribbling and shooting.

Each school has its own teaching media. Facilities and infrastructure of the schools is very limited especially in marginal schools. Physical health and sports education teacher often complain about the lack of basketball in doing the learning. In fact, it is impossible for every student to use one ball each. TGfU (Teaching Games for Understanding) approach is a solution when it will teach basic motion basketball especially if the school has limited balls. Learning stillwill be well conducted with a small game formed from TGfU (Teaching Games for Understanding)approach.

From the reviews mentioned above, the teacher does not need to worry when the school only has limited facilities and infrastructure, teachers must make active learning, and students do not wait to do the exercises during teaching learning process. Through the approach of teachers Teaching Games for Understanding, the learning will take place interestingly, all students will move up, no body wait, and learning can be carried out with simple or limitedequipment.

From the reviews above, the alternative of TGfU (Teaching Games for Understanding) to teach basketball is being discussed including: physical education in the development of Human Resources, developing cardiorespiratory to improve the quality of Human Resources, TGfU Teaching Games for Understandingmethods, and strategies for developing cardiorespiratory in basketball game.

\section{DISCUSSION}

\section{A. Physical Education in the Development of Human Resources}

Physical education is an education dealing with students' physical activity as a means of achieving educational goals. Increased organic development of the individual, perceptually, neuromuscular, cognitive, moral, and emotional conducted through physical education. Physical education learning requires the active movement of learners.

It is presented by Frost in the book Fundamentals of Physical Education written by Arma Abdullah and Agus Manadji (1994: 6), "Physical education consists of the changes and adjustments that occur in individuals when he/she moves and learn motion." Other definitions about physical education is delivered by Abdul Gafur in Arma Abdullah and Agus Manadji (1994: 5),

Physical education is a educationprocess of a person as an individual or as a member of society done consciously and systematically through intensive physical activity in order to improve capacity and physical skills, 
intelligence growth and the formation of character.

Physical fitness is very important in supporting daily activities, although the activity of each person is different according to the task and profession because physical fitness is the ability of the body or physical to carry out duties in accordance with the physical tasks such or physically able to perform certain tasks to get best results, therefore the physical conditions, whether he is fit or not, should be considered.

According Karpovich cited by Muhajir (2007: $161)$, he states that physical fitness is an ability to perform certain tasks that require muscle. Meanwhile, according to the Directorate General of sport and youth cited by Muhajir (2007: 161), physical fitness is the ability and capability to do the job efficiently without causing significant fatigue.

When the physical activity is well performed by students in schools with good teaching methods, including active activities to the students, then the students will perform these activities using the ability of the heart and lungs. When a teacher at the school has already provided cardiorespiratory fitness training activities, certainly students will always be fit, so that students can attend learning both inside and outside the classroom without any constraint.

\section{B. Development of Cardiorespiratory in Improving Human Resources Quality}

Humans can perform optimally when the organs in the human body are not impaired. Human organs can function properly if they want to train and develop them. If not trained then it will decline in organ function, which occurs when the function of human organs get decreased, ie, human quality in work. The most responsible human organs are the heart and lungs often called cardiorespiratory.

The term of cardiorespiratory fitness is similar to some other terms such as: cardiac endurance, cardiorespiratory endurance. According to Rush Lutan (2001: 46), technical understanding of cardio (heart), vascular (blood vessel), respiratory (lung and ventilation), aerobic (working with oxygen). The term is related to one another.

Cardiorespiratory durability is very important to support the muscles work by taking oxygen and distributing it throughout the muscle tissue that are active so that it can be used for metabolism. Good physical activity qualifying good activities is by considering the timing, intensity, frequency and type. Good activity will affect to the heart and lung function at the time of movement, then the oxygen needed by the body will also be the maximum influx.

As presented by Kris (1998: 24), cardiorespiratory enduranceis the ability of the circulatory system and respiratory to distribute oxygen and food to the muscles that work in accordance with the need to have goodcardiorespiratoryenduranceto recover fatiguemore quickly.

Indirectly, properly-trained cardiorespiratory will result a recovery from the activities he has done in case of fatigue. Cardiorespiratory is developed for the improvement of Human Resources through physical activity programs. The body with programmed- physical activity will obtain benefits. More weight would be given to the organsto strengthen the muscles in the walls of organs in humans. When the wall of human organs has been stronger, then there will not any difficulties or obstacles related to health,humans will perform daily activities to improve the quality of work. The mostconducivehuman organs to improve the quality of work are heart and lungs or cardiorespiratory.

This is confirmed by Ketut Iwan Swadesi (2007: 38), the most important elements in physical fitness is cardiorespiratory endurance. High cardiorespiratory endurance can maintain the appearance of a relatively long period of time continuously. Cardiorespiratoryfitness development is the most important component in a person's physical fitness. Cardiorespiratory fitness or durability of the heart, lung, is the ability of lung and heart to absorb and distribute oxygen to the muscles according to the needs. Someone who has a good level of fitness cardiorespiratory is more efficient in the use of oxygen so that he can perform daily activities without experiencing fatigue.

\section{Model of TGfU (Teaching Games for Understanding)}

Teachers have already applied a variety of learning models in delivering lessons in physical education in schools. The learning model used by the teacher is already good, the problem is only when the school does not have complete facilities. While teachers are required to be able to make an assessment and to implement strategies in teaching.

It was presented by Michael W. Metzler (2000: 12) stating that the model is designed to be used in the overall learning unit including all the functions of planning, design, implementation, and assessment for the unit. More than one type of learning methods, teaching styles, as well as learning strategies can be used in the study model.

There are many teaching models can be applied in the field when teaching physical education, but the learning model applied should be in accordance with the characteristics of the students. In addition to student characteristics, namely infrastructure and facilities owned by the school, then a good learning should be studentcentered learning, not dominated by the teacher. Learning should make students active.

Linda L. Griffin (2005: 1) says that the Teaching Gamesfor Understanding (TGfU) is a game and students centered learning to learn the game related to sports by using a constructive approach. Experts such as Griffin, Mitchell, and Osilin (2006: 4) argues that a 
learning approach using tactics approach will help students to develop skills and problem-solving skills in the game.

From some of these definitions, it can be concluded that the Teaching Games for Understanding learning model focuses on problem solving tactics through games carried by learners. The components of Teaching Games for Understandinglearning model developed by Bunker and Thrope in the book Teaching Games for Understanding (TGfU) written by Linda L. Griffin (2005: 50) are as follows,

a. Game. All students are able to play the game. Margaret Ellis (1986) outlined the benefits and means of "enabling" every child to participate, regardless of skill level, by modifying such things as rules, equipment, playing areas, and group size.

b. Game Appreciation. Students learn to understand and respect the necessity of rules because they create, implement, and refine them.

c. Tactical Awareness. Students come to know and understand the game trough solving problems as they are presented in game situations.

d. Decision Making, Students learn to make good decisions by practicing the elements of decision making. These elements include paying attention to relevant action (selective attention), anticipating responses by opponents, and choosing appropriate skills (those that will implement the decision most effectively).

e. Skill Execution, Students are motivated to learn skills because they are learned in context and practiced after the game is played. The skills then enhance game play performance and help students implement the chosen strategy.

f. Performance, the level of students' performance increases as the cycle continues.

The game in the Teaching Games for Understandinglearning model emphasizes the form of the game that should be tailored to the characteristics of the students and thestudents' stage of development. Game Appreciationcan be summed up as the conceptualization of the values in the game. Tactical Awareness can be defined as developing strategic thinking. MakingAppropriate Decisionis interpreted as an understanding of tactics, which make decisions and how to do it. Skill Execution can be defined as the implementation of motion by using techniques selected. Performance is playing skills supported by an understanding of tactics and execution of motion.

Mitchell, Oslin, and Griffin (2006: 17) presented the form of Learning Process Plan of Teaching Games for Understanding (TGfU)learning modelwhich consists of the problems of tactics, the focus of learning, assessment objects, and learning steps. Learning step includes the first game, the question, the task of training, the second game, and ended with a closing discussion.
Besides,Mitchell, Oslin, and Griffin (2006: 2021) classifies sport game in Teaching Games for Understanding (TGfU) into 4 groups, namely: (1) Target Games, the target games have rules that players will get the numbers when the ball or another kind of projectile either thrown or hit directing the target. Examples of the game are golf, bowling, snooker and billiards. (2) Net / Wall Games, team or individual game in which a score is obtained when players knock the ball to the opposite field and the opponent cannot return it. For example, badminton, tennis, table tennis, and volleyball. (3) Striking / Fielding Games, a team game to get scores by hitting a ball to be placed on a particular spot. The batter run and avoid pitching of the guard. Examples: baseball, softball, cricket, and rounder. (4) Invasion Games, a team game in which the score is obtained when a ball or similar projectile is able to enter the opponent's goal. For example, basketball, soccer, and water polo.

TGfU is a learning approach to students that fosters awareness of tactics and learning skills. TGfU is very effective in student-centered learning and focuses on the game. This learning approach requires students to understand the tactics and strategy of playing sport first before learning about the techniques used.

\section{Cardiorespiratory Development Strategies in Basketball}

Basically there are some indicators of the ability of students to play basketball that can be observedin TGFUincluding: games, game appreciation, tactical awareness, decision making, skill execution, and performance.

In learning basketball, indicators of skill execution include: reaching the target at the time of passing, using three types of passing, when receiving the ball, he can control and setup the pass properly, do dribbling below the waist in a controlled way, do the shooting with a ball over the top of the head or opponents' range and on target. Decision making include: the decision to pass to teammates, choosing any shooting appropriately. Support includes: a willingness to move so as to obtain the right position. Defending includes: blocking the ball and the opponent, and cooperate with teammates in constructing the attack. Scoring includescreating a score to win. Game Appreciation is the application of the values in the game, playing basketball in the tactic approachthat contains elements of the value of teamwork, discipline, respect, uphold the rule, students who take the learning basketball using tactics approach is expected to know the value of a game done.

Tactical Awareness can be defined as developing ways to plan strategies while playing. In the tactic approach, students will face the problems in the field during play time, students must think and make decisions and develop strategies to win the game.

Making Appropriate Decision is interpreted as thinking skills to take decisions, which make decisions and how to do it. Tactics Approachused in basketball game in junior high school students will come up with a 
decision that will be made by the students while playing. It makes the students have to think fast in taking decisions to produce good results.

Skill Execution can be defined as a skill in executing the ball using proper techniques in a play, basketball game that will be studied by junior high school students are the basic motion of passing, dribbling, and shooting. At the time of playing the students will get problems that must be solved with the basic movements, by conducting appropriate correct technique.

Performance is defined as the ability of students to build a good game. Of course this should be supported by playing skills, understanding tactics, and execution of motion. Student performance when playing basketball determine the success of the tacticsapproach, because when students do a good game, students will play in accordance with their respective responsibilities. Students tactics is correctly done during the play then supported by the motion that correspond to the learning objectives to be achieved.

Mitchell, Oslin, and Griffin (2006: 17) wrote that the forms of Learning Process Plan of Teaching Games for Understanding (TGfU) learning model consists of the problems of tactics, the focus of learning, assessment objects, and learning steps. Learning step includes the first game, the question, the task of training, the second game, and ended with a closing discussion. Selin was Mitchell, Oslin, and Griffin (2006: 20-21) classifies sport game in Teaching Games for Understanding (TGfU) into 4 groups, namely: (1) Target Games have rules that players will get the scores when the ball or another kind of projectile either thrown or hit the target directly. Examples of the game are golf, bowling, snooker and billiards. (2) Net / Wall Games, team or individual game in which a score is obtained when players knock the ball to the opposite field and the opponent cannot return it. For example, badminton, tennis, table tennis, and volleyball. (3) Striking / Fielding Games, a team game will get scores by hitting a ball to be placed on a particular spot. The batter run and avoid pitching of the guard. Examples of games: baseball, softball, cricket, and rounders. (4) Invasion Games, a team game in which the score is obtained if a ball or similar projectile able to enter the opponent's goal. For example, play basketball, soccer, and water polo.

a. The Advantages of TGFULearning Model

Basketball learning with TGFU has the following advantages: (1) Learning will be more fun so that students are receptive to learning materials, (2) it provides opportunities for students to be active in the game, (3) students can construct playing skills gradually, (4) students builds their own team work determined by the teacher, (5) teachers can assess students more authentic based on the game.

b. Disadvantages of TGFULearning Model

The disadvantages of the TGFUlearning model are as follows: (1) students have insufficient drill game techniques in relatively short time, (2) learning model
TGFU require settled preparation, because without adequate preparation learning model TGFU can fail to cause this model is not effective. (3) TGFU learning model requires the ability and skills of special teachers, so the teachers are required to work more professionally. In addition, TGFU learning model also requires the willingness and motivation of a good teacher for the success of the learning process of students, (4)from the indicator of TgfU learning model achievement, the students' achievement are not equal due to the relative students'scoring achievement.

Students' abilityto play basketball well can be seen from invasion game done, invasion game performed by the students reflected the execution skills, decision making, support, defending and scoring. Mitchell, Oslin, and Griffin (2006: 20-21) mention the criteria of skill execution, decision making, support, defending and scoring are as follows:

1) Skill execution include: reaching the target at the time of passing, using three types of passing, controlling the pass and setting up properlywhen receiving the ball, doing dribbling below the waist in a controlled way, doing the shooting with a ball over the top of the head or reach the opponent and on target

2) Decision making include: the decision to pass to teammates, choose any shooting appropriately.

3) Support includes: a willingness to move to obtain the right position.

4) Defending include: blocking the ball and the opponent, and cooperate teammates in constructing the attack.

5) Scoring includes creating a score for victory

Learning physical education, especially basketball games conducted at the school still requires students to master the technique. Moreover, teaching physical education has the goal of improving physical fitness or cardiorespiratory. Because the mastery of technique is more in practice, particularly learning basketball game, most teacher apply drilling method. This method is suitable to be used, but the students feel bored, waiting for the motion trained by the teacher. Then students will waste their time to wait because it is not possible for all students to hold their own ball. Students also cannot utilize their move, so they cannot explore maximally. By applying drilling method, a teacher feels comfortable, he only needs to instruct, then students will move by themselves.

Learning by using TGfU as described aboveprovides an alternative in teaching physical education, especially in basketball by implementing invasionwhich contains the elements of basketball. 
Table1. Application of Invansion Game Within Game Containing Elements In Basketball Game

\begin{tabular}{|c|c|c|}
\hline Stages & Description & $\begin{array}{l}\text { Implementatio } \\
\text { nSamples in } \\
\text { the field }\end{array}$ \\
\hline $\begin{array}{l}\text { Skill } \\
\text { execution }\end{array}$ & $\begin{array}{l}\text { Reaching the } \\
\text { target at the } \\
\text { time of passing, } \\
\text { using three } \\
\text { types of passing, } \\
\text { being able to } \\
\text { being able to } \\
\text { control and } \\
\text { setup the pass } \\
\text { properly, doing } \\
\text { dribbling below } \\
\text { the waist in a } \\
\text { controlled way, } \\
\text { doing the } \\
\text { shooting with a } \\
\text { ball over the top } \\
\text { of the head or } \\
\text { the opponents' } \\
\text { range and on } \\
\text { target. }\end{array}$ & $\begin{array}{l}\text { Students are } \\
\text { divided into two } \\
\text { groups. They do } \\
\text { passing, } \\
\text { dribbling and } \\
\text { shooting into } \\
\text { the ring. The } \\
\text { ball should be } \\
\text { more than one, } \\
\text { so all students } \\
\text { do the } \\
\text { movement. } \\
\text { Once completed } \\
\text { in accordance } \\
\text { with the given } \\
\text { time, then the } \\
\text { game is stopped. } \\
\text { The teacher's } \\
\text { role is to } \\
\text { provide } \\
\text { feedback on the } \\
\text { game done by } \\
\text { the students } \\
\text { earlier After } \\
\text { that, the } \\
\text { students are } \\
\text { asked to do the } \\
\text { game in } \\
\text { accordance with } \\
\text { the explanation } \\
\text { of the teacher. }\end{array}$ \\
\hline $\begin{array}{l}\text { Decision } \\
\text { making }\end{array}$ & $\begin{array}{l}\text { The decision to } \\
\text { pass to } \\
\text { teammates, } \\
\text { choose any } \\
\text { shooting exactly }\end{array}$ & $\begin{array}{l}\text { Students do } \\
\text { passing game by } \\
\text { using the game } \\
\text { three on three or } \\
\text { three against } \\
\text { three, students } \\
\text { play the ball } \\
\text { only by passing } \\
\text { and shooting. } \\
\text { The role of the } \\
\text { teacher after the } \\
\text { game is stopped } \\
\text { is that the } \\
\text { teacher gives } \\
\text { correction on } \\
\text { implementation } \\
\text { of passing and } \\
\text { shooting. After } \\
\text { that, the } \\
\text { students are } \\
\text { asked to do the } \\
\text { game again. }\end{array}$ \\
\hline
\end{tabular}

Table 1. Continued

\begin{tabular}{|c|c|c|}
\hline Support & $\begin{array}{l}\text { The } \\
\text { willingnesst } \\
\text { o move so as } \\
\text { to obtain the } \\
\text { exact } \\
\text { position. }\end{array}$ & $\begin{array}{l}\text { Students do defense and } \\
\text { attack. There are two } \\
\text { groups as defense and } \\
\text { attack. In this case the } \\
\text { student will attack by } \\
\text { passing and shooting. Once } \\
\text { the game is finished, the } \\
\text { teachers give feedback to } \\
\text { the students by providing a } \\
\text { correction on the } \\
\text { movement of students to } \\
\text { acquire the appropriate } \\
\text { position. Having finished } \\
\text { describing, the students are } \\
\text { asked to continue the game } \\
\text { back. }\end{array}$ \\
\hline Defending & $\begin{array}{l}\text { Against the } \\
\text { ball and the } \\
\text { opponent to } \\
\text { cooperate in } \\
\text { building a } \\
\text { teammate. }\end{array}$ & $\begin{array}{l}\text { Students perform defense } \\
\text { and attack game. There are } \\
\text { two groups as defense and } \\
\text { attack. In this case the } \\
\text { student will play attack by } \\
\text { passing, dribbling, and } \\
\text { shooting } \\
\text { Once the game is finished, } \\
\text { the teachers give feed back } \\
\text { to the students by } \\
\text { providing a correction on } \\
\text { the movement of students } \\
\text { to have aappropriate } \\
\text { position of defense and } \\
\text { attact. Having finished } \\
\text { describing, the students are } \\
\text { asked to continue the game } \\
\text { back. }\end{array}$ \\
\hline Scoring & $\begin{array}{l}\text { Creating } \\
\text { score to win }\end{array}$ & $\begin{array}{l}\text { Students do defense and } \\
\text { attack. There are two } \\
\text { groups as defense and } \\
\text { attack. In this case the } \\
\text { student will play attack by } \\
\text { passing, dribbling, and } \\
\text { shooting. } \\
\text { Once the game is finished, } \\
\text { the teachers give feed back } \\
\text { to the students by } \\
\text { providing a correction in } \\
\text { creating score. Having } \\
\text { finished describing, the } \\
\text { students are asked to } \\
\text { continue the game back.. }\end{array}$ \\
\hline
\end{tabular}




\section{Conclusion}

Physical education to form students' healthy and fit performance and good personality. The values in physical education when applied in everyday life will support the development of learners in a positive direction. Physical education has a lot of physical activity that can be done in schools, one of them is through game activity, namely basketball game.

Basketball is played by two teams with 5 players per team. The goal is to get a score to put the ball into the ring and prevent other teams to do the same. The ball can be given only by passing by hand or by dribbling it several times on the floor without touching it with two hands simultaneously. Basketball is a sport that is played using a basketball board, ring and ball by shooting, dribbling, and passing ranging from relatively slow to very fast movement accompanied by a trick. In the game of basketball, every basic motion taught by using TGfU methodswill make students become active. Students are active in physical education at the basketball game so that children move on and have a good cardiorespiratory fitness.

In learning basketball, indicators of skill execution include: reaching the target when passing by using three types of passing, being able to controland setupthe pass properly, doing dribbling below the waist in a controlled way, doing the shooting with a ball over the top of the head or opponents' range and on target. Decision making include: the decision to pass to teammates and to choose any shooting appropriately. Support includes: a willingness to move so as to obtain the right position. Defending include: blocking the ball and the opponent, and cooperate teammates in building the attack. Scoring includes creating a score to win the game. Game Appreciation is the application of the values in the game, playing basketball in tacticsapproach contains value elements of teamwork, discipline, respect, uphold the rule, students who take the learning basketball using tactics approach is expected to know the value of a game done.

\section{BIBLIOGRAPHY}

Arma Abdullah \& Agus Manadji. (1994). Dasar-Dasar Pendidikan Jasmani. Jakarta: Direktorat Jenderal Pendidikan Tinggi Departemen Pendidikan dan Kebudayaan.

Ayi Suherman. (2009). Pengembangan model pembelajaran outdoor education pendidikan jasmani berbasis kompetensi di Sekolah Dasar. $\quad$ Tersedia http://jurnal.upi.edu/file/ayi.pdf. Diunduh tanggal 16 Oktober 2015.

BSNP. (2006). Standar isi untuk satuan pendidikan dasar dan menengah. Jakarta: Depdiknas.
Metzler, Michael W. (2000). Instructional Models for Physical Education. United States of America: Allyn and Bacon.

Mitchell, G. Duncan (ed). (1979). A New Dictionary of the Social Sciences. New York: Aldine Publishing Company.

Muhajir.(2007). Pendidikan Jasmani Olahraga dan Kesehatan. Jakarta: Erlangga.

Oliver, Jon. (2007). Basketball fundamentals. Chapaign: Human Kinetic PublisherInc.

Mitchell, Stephen A., Oslin, Judith L., \& Griffin, Linda L. (2006). Teaching Sport Concepts and Skills. United States of America: Human Kinetics.

Wissel Hall. (2000). Bola basket dilengkapi dengan program pemahiran tekhnikdan taktik. (Terjemahan Bagus Pribadi). Chapaign: Human Kinetics. (Buku asli diterbitkan tahun 1994).

Wissel Hall. (2004). Basketball steps to succes. New Jersey: Human Kinetics. 